\begin{tabular}{c} 
Benha Veterinary Medical Journal \\
$\begin{array}{c}\text { Official Journal Issued by } \\
\text { Faculty of } \\
\text { Veterinary Medicine }\end{array}$ \\
\hline
\end{tabular}

Original Paper

\title{
Natural preservatives in raw chicken meat
}

\author{
Fatin S. Hassanien', Fahim A. Shaltout ${ }^{1}$, Seham N. Homouda ${ }^{2}$ and Safaa M. Arakeeb ${ }^{3}$ \\ ${ }^{1}$ Food Hygiene Dept. (Meat Hygiene), Fac.Vet. Med., Benha University, Egypt \\ ${ }^{2}$ Food Hygiene Dept., Animal Health Research Institute, Tanta laboratory, Egypt \\ ${ }^{3}$ Veterinarian, Directorate of Veterinary Medicine, El-Gharbia, Egypt
}

\section{ARTICLE INFO}

\begin{tabular}{l}
\hline Keywords \\
Clove oil \\
Cinnamon oil \\
E. coli \\
Essential oils \\
Staph. aureus \\
\hline Received $13 / 10 / 2019$ \\
Accepted 15/12/2019 \\
Available On-Cine \\
12/05/2020
\end{tabular}

\begin{abstract}
Cinnamon and clove essential oils were evaluated for their effects on the growth and survival of Staphylococcus aureus (S. aureus) and Escherichia coli (E. coli) artificially inoculated into raw chicken meat. Fresh minced chicken meat samples were inoculated with $(6 \mathrm{log} \mathrm{cfu} / \mathrm{g})$ of $S$. aureus and E. coli. Cinnamon and clove oils were added to the minced chicken meat samples to achieve final concentrations of $0.5 \%$ and $1 \%$. Sensory (color, odor and texture) and bacteriological analyses were conducted after $24 \mathrm{hrs}$ for E.coli and every $48 \mathrm{hrs}$ for $S$. aureus during cold storage at $4{ }^{\circ} \mathrm{C}$. The results concluded that the addition of clove oil by $1 \%$ concentration had a powerful effect in reducing $S$. aureus that can cause food poisoning, while cinnamon oil $1 \%$ had good effect on E. coli but had strong flavor so from this study the authors found that clove oil at $1 \%$ and cinnamon at $0.5 \%$ had improved the flavor and extended the shelf life of fresh chicken meat.
\end{abstract}

\section{INTRODUCTION}

Poultry meat is a very popular food and is preferred by consumers due to low production cost, low fat content and high nutritional value. Considering the fact that poultry meat belongs to perishable foods, the main concern of industries is the shelf life extension of the poultry meat. Modern trends to achieve this target include the application of the hurdle technology concept and the use of natural food preservatives so as to sustain minimal processing and also to provide protection from both spoilage and pathogenic microorganisms (Khiari et al., 2014).

Staphylococcal food-borne disease (SFD) is one of the most common food-borne diseases worldwide, resulting from the consumption of food that already contaminated by preformed $S$. aureus enterotoxins. This toxin resulting in sudden onset of nausea, vomiting and abdominal cramps (Unal and Cinar, 2012), while E. coli is often found in our surrounding environment because of fecal contamination (Ferens and Hovde et al., 2011)and It is characterized by causing abdominal cramping, pain, fever, nausea , vomiting ,hemorrhagic colitis and bloody diarrhea (Abongo and Momba, 2009).

Cinnamon is considered a common spice with strong antimicrobial and antioxidant activity. It belongs to the family Lauraceae and possesses significant biological activities (antitumor, antifungal, cytotoxic and antimutagenic) attributed to the cinnamaldehyde. The ability of this extract to retard lipid oxidation is attributed to the ability of its phenolic constituents to quench reactive oxygen species (Bonilla and Sobral, 2016).
Clove essential oil has a wide spectrum of actions not only antibacterial, antiviral, antifungal and antiprotozoal, but also have beneficial effects on the cardiovascular and immune system. It has the ability to inhibit the growth of $S$. aureus in meat products. The antibacterial activity of clove is attributed to eugenol with a small addition of cariophyllene and humulene (Daniel et al., 2009).

Therefore, the aim of the present work was to evaluate the efficacy of clove and cinnamon essential oils as antimicrobial agents in chicken minced meat by screening their bactericidal activities against $S$. aureus and E.coli.

\section{MATERIAL AND METHODS}

\subsection{Samples:}

Sixty samples of raw chicken meat (breast and thigh) were collected from different chicken retails in Gharbia governorate, Egypt. All collected samples were separately kept in a sterile plastic bag and transferred in an ice box to the laboratory under complete aseptic conditions without undue delay and examined as quickly as possible. The samples were subjected to the bacteriological examination for $S$. aureus and E. coli with serological examination for isolated E. coli.

\subsection{Natural oils:}

The essential oils (cinnamon and clove) were purchased from "The Agricultural Research Centre, Dokki, Egypt "which were produced by hydro-distillation method.

* Corresponding author: Safaa M. Arakeeb. Veterinarian, Directorate of Veterinary Medicine, El-Gharbia, Egypt 


\subsection{Experimental application:}

In three trials, a total $3600 \mathrm{gm}$ of fresh chicken breast were purchased directly from different local markets in Gharbia governorate, Egypt. In each trial, the samples (1200 gm) were divided into six equal groups (100 gm each) for S. aureus trial and other six equal groups (100 gm each) for E. coli trial. All samples were washed in sterile distilled water and were properly labeled as: control (-ve), control (+ve), cinnamon oil ( $0.5 \%$ and $1 \%)$ and clove oil $(0.5 \%$ and $1 \%)$. Each group of artificially inoculated chicken breast samples with previously isolated S. aureus and E.coli O119 $\left(10^{6}\right.$ $\mathrm{cfu} / \mathrm{ml}$ ) were inoculated by essential oils ( cinnamon and clove, which dissolved in tween 80) at room temperature $\left(25 \pm 1^{\circ} \mathrm{C}\right)$ except control samples. All the samples treated with essential oils and the control groups were packed in polyethylene bags; labeled and stored at $4{ }^{\circ} \mathrm{C}$.

All groups were sensory examined for color, odor and texture every day ( $24 \mathrm{hrs}$ ) during storage period. S. aureus count was conducted on Baird Parker Plate media every 48 hrs during that period, while E. coli count was recorded on E.M.B media every $24 \mathrm{hrs}$, during the same period, using the serial dilutions and spread plate technique (Jay, 1992).

\subsection{Statistical analysis:}

The obtained results were statistically evaluated by application of analysis of variance (ANOVA) test according to Feldman et al. (2003).

\section{RESULTS}

Table (1) revealed that mean value of $S$. aureus in examined chicken meat samples were $5.00 \pm 4.37 \mathrm{log} \mathrm{cfu} / \mathrm{g}$ represented by $5.20 \pm 4.65 \mathrm{log} \mathrm{cfu} / \mathrm{g}$ in breast and $4.80 \pm$ $4.22 \mathrm{log} \mathrm{cfu} / \mathrm{g}$ in thigh samples. While the prevalence $\%$ of E. coli in same examined samples was $(42.8 \%)$ in breast and $(62.5 \%)$ in thigh samples.

The results recorded in table (2) revealed that E. coli serologically detected as $\mathrm{O} 119$, O125 and $\mathrm{O} 111$ in a percent 40,10 and $20 \%$, respectively.

Table 1 Statistical analytical results of S. aureus and E. coli count (log cfu/g) of the examined samples of chicken meat.

\begin{tabular}{cccc}
\hline Samples & $\begin{array}{c}\text { No. of examined } \\
\text { samples }\end{array}$ & $\begin{array}{c}\text { Mean value of S. aureus } \\
\pm \text { S.E }\end{array}$ & $\begin{array}{c}\text { Prevalence \% of } \\
\text { E.coli }\end{array}$ \\
\hline Breast & 28 & $5.20 \pm 4.65$ & 42.8 \\
Thigh & 32 & $4.80 \pm 4.22$ & 62.5 \\
Total & 60 & $5.00 \pm 4.37$ & 53.3
\end{tabular}

The value represent mean \pm SD Of three experiments.

Table 2 Serotyping of isolated E. coli $(\mathrm{n}=10)$

\begin{tabular}{ccc} 
Table 2 Serotyping of isolated E. coli $(\mathrm{n}=10)$. & \\
\hline Serotypes & No. of E.coli isolates & percent $\%$ \\
\hline O119 & 4 & 40 \\
O125 & 1 & 10 \\
O111 & 2 & 20 \\
\hline
\end{tabular}

Result in table (3) and table (4) showed the antimicrobial effects and reduction percentage of various concentrations of clove and cinnamon oils on S. aureus count artificially inoculated into chicken breast minced meat. Clove oil $(0.5 \%$ and $1 \%)$ decreased the count of S. aureus $(\log \mathrm{cfu} / \mathrm{g})$ from $8.70 \pm 7.76 \mathrm{log} \mathrm{cfu} / \mathrm{g}$ (initial load) to $5.60 \pm 5.06 \mathrm{log}$ $\mathrm{cfu} / \mathrm{g}$ and $3.50 \pm 3.10 \mathrm{log} \mathrm{cfu} / \mathrm{g}$ with reduction percentages $35.6 \%$ and $60 \%$ on $8^{\text {th }}$ day and $12^{\text {th }}$ day of storage, respectively. Cinnamon oil $(0.5 \%$ and $1 \%)$ decreased the count of $S$. aureus $(\log \mathrm{cfu} / \mathrm{g})$ from $8.70 \pm 7.76 \mathrm{log} \mathrm{cfu} / \mathrm{g}$ (initial load) to $6.60 \pm 6.07 \mathrm{log} \mathrm{cfu} / \mathrm{g}$ and $5.50 \pm 5.18 \mathrm{log}$ cfu/g with reduction percentages $24 \%$ and $37 \%$ on $6^{\text {th }}$ day of storage, respectively.

The results recorded in table (5) revealed that the shelf life of examined samples artificially inoculated with $S$. aureus and treated with cinnamon $(1 \%)$, clove $(0.5 \%)$ and clove $(1 \%)$ reached 6, 9 and 12 days of storage, respectively .

Moreover, the results in table (6) and table (7) illustrated that the antimicrobial effects and reduction percentage of various concentrations of clove and cinnamon oils on $E$. coli count artificially inoculated into chicken breast minced meat using clove oil $(1 \%)$ revealed that it decreased the count of E. coli (log cfu/g) from $6.70 \pm 6.06 \log \mathrm{cfu} / \mathrm{g}$ (initial load) to $5.70 \pm 5.06 \mathrm{log} \mathrm{cfu} / \mathrm{g}$ with reduction percentages $15 \%$ on 1 shday of storage, while clove oil $(0.5 \%)$ showed no reduction in count of $E$. coli. Cinnamon oil $(0.5 \%$ and $1 \%)$ decreased the count of E. coli (log cfu/g) from $6.70 \pm 6.06 \mathrm{log} \mathrm{cfu} / \mathrm{g}$ (initial load) to $3.70 \pm 3.06 \mathrm{log}$ $\mathrm{cfu} / \mathrm{g}$ and $0 \mathrm{log} \mathrm{cfu} / \mathrm{g}$ with reduction percentages $45 \%$ and $100 \%$ on 5 thday of storage, respectively.

Furthermore, the results recorded in table (8) revealed that the shelf life of examined samples artificially inoculated with $E$. coli and treated with cinnamon $(1 \%)$ and cinnamon $(0.5 \%)$ reached 5 and 4 days of storage, respectively .

\section{DISCUSSION}

Staphylococci exist in air, dust, equipment, food, environmental surfaces, humans and /or animals. Staphylococci usually present in the nasal passage, throat, on the hair and skin (FDA, 2012). S. aureus which is the third most common cause of food poisoning in the world (Acco et al., 2003).Different stages of slaughter such as scalding, de-feathering and chilling may affect the prevalence and bacterial load of S. aureus on the carcasses (Spescha et al., 2006).

Mean values of $S$. aureus in examined chicken meat samples were nearly similar to the results conducted by El Allaoui et al. (2013) and Saad et al. (2018) and were higher than Abo El- Enean-Hanan et al. (2008) and Abd ElRahman et al. (2010), but these results were lower than Ahmad et al. (2013).

The reason for the relatively high prevalence of $S$. aureus in this research may be due to the bad personal hygiene of the workers and the traditional hand evisceration of chicken carcasses predominantly practiced in Egypt.

Prevalence of $E$. coli in examined chicken meat samples were nearly similar to that obtained by Rahman et al. (2017) $(49.02 \%)$ in chicken meat and Xuan Binh et al. (2017) 43.3\%. Meanwhile, the current study was higher than that conducted by Abd El-Rahman et al. (2010) (10.6\%) and Shaltout et al. (2018) (37,7\%). Moreover, these results were lower than that conducted by Eyi-Ayla and Arslan-Seza (2012) (87.5\%) and Hmd-Randa et al. (2017) $(82 \%)$. High prevalence of E.coli is good indicator to fecal contamination, water pollution and lack of sanitary condition during hand evisceration and washing of chicken carcasses. Clove oil is obtained from distillation of the flowers, stems, and leaves of the clove tree (Eugenia aromatica). 
Table 3 The effects of various concentrations of essential oils on S. aureus count (log cfu/g) of the examined chicken minced meat samples during cold storage at $40{ }^{\circ} \mathrm{C}$.

\begin{tabular}{lccccccc}
\hline Treated samples & \multicolumn{7}{c}{$==========$ Storage days $===========$} \\
& 0 day & 2nd day & 4th day & 6th day & 8th day & 10 day & 12 day \\
\hline Clove 0.5\% & $8.7 \pm 7.76$ & $7.7 \pm 7.06$ & $6.8 \pm 6.06$ & $5.7 \pm 5.06$ & $5.6 \pm 5.06$ & $7.6 \pm 7.19$ & $8.7 \pm 8.06$ \\
Clove 1\% & $7.6 \pm 6.94$ & $6.7 \pm 6.06$ & $5.6 \pm 4.94$ & $4.7 \pm 4.16$ & $4.6 \pm 4.06$ & $3.7 \pm 3.06$ & $3.5 \pm 3.1$ \\
Cinnamon 0.5\% & $8.7 \pm 8.06$ & $8.5 \pm 7.76$ & $7.6 \pm 7.06$ & $6.6 \pm 6.07$ & $7.6 \pm 7.07$ & $8.6 \pm 8.33$ & $8.8 \pm 8.07$ \\
Cinnamon 1\% & $8.6 \pm 7.94$ & $8.6 \pm 8.06$ & $6.7 \pm 6.06$ & $5.5 \pm 5.18$ & $6.6 \pm 6.16$ & $8.6 \pm 8.06$ & $8.8 \pm 8.06$
\end{tabular}

The value represent mean \pm SD Of three experiments.

Table 4 Reduction $\%$ in S. aureus count of the examined chicken minced meat samples during cold storage at $4^{\circ} \mathrm{C}$.

\begin{tabular}{lrrrrrrr}
\hline Groups & 0 day & 2nd day & 4th day & 6th day & 8 th day & 10 day & 12 day \\
\hline Clove 0.5\% & -- & 11.5 & 22 & 34.5 & 35.6 & 12.64 & -- \\
Clove 1\% & 12.64 & 23 & 35.63 & 46 & 47 & 57.5 & 60 \\
Cinnamon 0.5\% & -- & 2 & 12.64 & 24 & 12.64 & 1 & -- \\
Cinnamon 1\% & 1 & 1 & 23 & 37 & 24 & 1 & -- \\
\hline
\end{tabular}

No reduction.(--)

Table 5 Sensory evaluation of treated chicken minced meat samples with various concentrations of essential oils for S. aureus artificially inoculated in minced chicken meat samples during cold storage at $40{ }^{\circ} \mathrm{C}$.

\begin{tabular}{lccccccc}
\hline \multicolumn{1}{c}{ Groups } & 0 day & 2nd day & 4th day & 6th day & 8th day & 10 day & 12 day \\
\hline Clove $0.5 \%$ & 8 & 7 & 6 & 5 & 4 & 3 & 2 \\
Clove 1\% & 9 & 9 & 8.5 & 8 & 6 & 5.5 & 5 \\
Cinnamon $0.5 \%$ & 8 & 7 & 6 & 4.5 & 3 & 2 & 1 \\
Cinnamon $1 \%$ & 8 & 7 & 5 & 4 & 3 & 2 & 1
\end{tabular}

Score System for Sensory Evaluation (Pearson and Tauber, 1984):

$\begin{array}{lll}\text { 9: Excellent } & \text { 6: Good } & \text { 3: Poor }\end{array}$

8: Very very good $\quad$ 2: Medium $\quad$ Very poor

7: Very good $\quad 4$ : Fair $1:$ Very very poor

Table 6 The effects of various concentrations of essential oils on $E$. coli count (log cfu/g) of the examined chicken minced meat samples during cold storage at $4^{0} \mathrm{C}$.

\begin{tabular}{lcccccc}
\hline Treated samples & \multirow{5}{c}{$==========$} & Storage days $===========$ \\
& 0 day & 1st day & 2nd day & 3rd day & 4th day & 5th day \\
\hline Clove 0.5\% & $6.7 \pm 6.06$ & $6.7 \pm 6.06$ & $6.8 \pm 6.16$ & $8.7 \pm 7.94$ & $8.8 \pm 7.94$ & spoiled \\
Clove 1\% & $6.7 \pm 6.06$ & $5.7 \pm 5.06$ & $6.7 \pm 6.16$ & $8.7 \pm 7.94$ & $8.8 \pm 7.94$ & spoiled \\
Cinnamon 0.5\% & $5.8 \pm 5.06$ & $5.6 \pm 5.06$ & $5.6 \pm 4.94$ & $4.7 \pm 4.16$ & $4.7 \pm 3.94$ & $3.7 \pm 3.06$ \\
Cinnamon 1\% & $5.7 \pm 5.07$ & $4.7 \pm 4.06$ & $3.6 \pm 3.07$ & $2.7 \pm 2.06$ & $2.6 \pm 2.06$ & $\begin{array}{l}\text { Non } \\
\text { detectable }\end{array}$ \\
\hline
\end{tabular}

The value represent mean \pm SD of three experiments (initial count $=6.7 \pm 6.06$ )

Table 7 Reduction \% in E.coli count of the examined chicken minced meat samples during cold storage at $40{ }^{\circ} \mathrm{C}$.

\begin{tabular}{lcccccc}
\hline Groups & 0 day & 1st day & 2nd day & 3rd day & 4th day & 5th day \\
\hline Clove $0.5 \%$ & -- & -- & -- & -- & - & -- \\
Clove $1 \%$ & -- & 15 & -- & -- & -- & -- \\
Cinnamon $0.5 \%$ & 13.5 & 16.4 & 16.4 & 30 & 30 & 45 \\
Cinnamon $1 \%$ & 15 & 30 & 46 & 60 & 61 & 100 \\
\hline No reduction $(-)$ & & & & &
\end{tabular}

Table 8 Sensory evaluation of treated chicken minced meat samples with various concentrations of essential oils for E. coli artificially inoculated in minced chicken meat samples during cold storage at $40{ }^{\circ} \mathrm{C}$.

\begin{tabular}{|c|c|c|c|c|c|c|}
\hline Groups & 0day & $1^{\text {st }}$ day & $2^{\text {nd }}$ day & $3^{\text {rd }}$ day & $4^{\text {th }}$ day & $5^{\text {th }}$ day \\
\hline Clove $0.5 \%$ & 6 & 5 & 4.5 & 3 & 2 & 1 \\
\hline Clove $1 \%$ & 6 & 5 & 4 & 3 & 2 & 1 \\
\hline Cinnamon $0.5 \%$ & 6 & 5.5 & 5 & 4 & 4 & 3.5 \\
\hline Cinnamon $1 \%$ & 6 & 6 & 5.5 & 5 & 4 & 4 \\
\hline \multicolumn{7}{|c|}{ Score System for Sensory Evaluation (Pearson and Tauber, 1984): } \\
\hline $\begin{array}{l}\text { 6: Excellent } \\
\text { 3: poor }\end{array}$ & & \multicolumn{3}{|c|}{ 5: Very good } & \multicolumn{2}{|c|}{ 4: Good } \\
\hline
\end{tabular}

Amongst other components of the clove oil is the phenylpropene eugenol which is responsible for the distinctive aroma of the clove oil, with eugenol making up about $70-90 \%$ of the clove oil (Safrudin et al., 2015). Clove oil has been reported to have various degrees of antimicrobial activity against pathogens (Mishra and Kalyani, 2014).

Clove $1 \%$ cause obviously inhibition of $S$. aureus growth beginning from 0 day till end of storage period so high concentration of clove oil $(1 \%)$ more effective in 
decreasing S. aureus count than low concentration $(0.5 \%)$. The antimicrobial action of clove oil is related to its ability to inactivate microbial adhesion, enzymes and cell envelope proteins (Marí et al., 2004).

While cinnamon oil $1 \%$ cause slight inhibition of $S$. aureus growth at $4^{\text {th }}$ day and $6^{\text {th }}$ day then count increase again.

These results were in agreement with results recorded by Hassanien-Fatin et al. (2016) and Abd El - Hamed-Naglaa et al.(2017). The results of my study revealed that clove oil potentially effective against $S$. aureus than cinnamon oil and were agree with that of Al-dhaher -Zainab (2008).

On the other side cinnamon oil is more effective against E.coli than clove oil and these results were agree with that obtained by Adesiji et al. (2015) and Raeisi et al. (2015) who mentioned that cinnamon essential oil showed higher antimicrobial activity against $E$. coli, but were in disagreement with Asha et al. (2014), who found that clove oil had high antibacterial activity against $E$. coli.

The results of my study revealed that clove oil more effective against $S$. aureus than E.coli and were agreet with that recorded by Hoqu et al. (2008) and Nzeako et al. (2006)

Gram positive bacteria are more sensitive than Gram negative to antimicrobial compounds of spice, such as phenols, aldehydes, ketones and terpenes (Nychas, 1995). In general, the difference lies in that the Gram negative bacteria cell wall is thinner than the Gram positive's cell wall, also the Gram negative cell wall has an outer membrane with a high percent of lipids that protects the cell wall taking into account that the cell wall is essential for keeping the cell integrity (Dourou et al., 2009).

A wide variety of microorganisms including $S$. aureus produce lipolytic enzymes that hydrolyze lipids, producing readily oxidizable substrates that have a rancid odor. E. coli produce proteolytic enzymes that hydrolyze proteins in foods leading to offensive odor. Most groups of microorganisms can spoil food by growing on the surface. Similarly, color changes in food can occur because of the surface growth of microorganisms (Sperber, 2009).

\section{REFERENCES}

1. Abd El-Hamed-Naglaa, A. (2017): Effect of essential oils on safety and shelf life of some chicken products. Ph.D., Thesis, Fac. Vet. Med., Benha Univ., Egypt.

2. Abd El Rahman, H. A.; Soad, A. S.; Mona, M. A. and Amany, M. A. (2010): Microbiological evaluation of frozen chicken nuggets and strips. SC.V.M.J., XV (1):121-131.

3. Abo El-Enean- Hanan, N.H.; El- Lawendi, M.T. and Asaad, A.M. (2008): Control of L.monocytogens and Staphylococcus aureus isolated from chicken meat and chicken products by dipping in some organic acid solutions. Bull. Anim. Hlth. Prod. Afr.,56(4):271-279.

4. Abongo, B. O. and Momba, M. N. (2009): Prevalence and characterization of Escherichia coli $\mathrm{O} 157: \mathrm{H} 7$ isolates from meat and meat products sold in Amathole District, Eastern Cape Province of South Africa. Food Microbiology J., 26: 173-176

5. Acco, M.; Ferreira, F.S.; Henriques, J.A.P. and Tondo, E.C. (2003): Identification of multiple strains of Staphylococcus aureus colonizing nasal mucosa of food handlers. Food Microbiol. 20: 489-493.

6. Adesiji,Y.O. ;Alli,O.A.T.; Shittu,A.A and Oluremi, A.S.(2015):Antibacterial activity of cinnamon and clove oil on different food borne bacterial isolates . Nig. J. Pure \& Appl. Sci.28: 2610 - 2616

7. Ahmad, M.U.D.; Sarwar, A.; Najeeb, M.I.; Nawaz, M.; Anjum, A.A.; Ali, M.A. and Mansur, N. (2013): Assessment of microbial load of raw meat at abattoirs and retail outlets. J. Anim. plant sci., 23(3): 745- 748 .

8. Al-dhaher -Zainab,A. (2008):The antibacterial activity of aqueous extract of cinnamon and clove against Staphylococcus aureus. Journal of Al-Nahrain University, 11(2):131-135

9. Asha,K.; Sunil,B.; George,G. and Prejit(2014): Effect of clove on the bacterial quality and shelf life of chicken meat. J. Meat. Sci. and Tech., 2 (2):37-39.

10. Bonilla, J. and Sobral, P.J.A.(2016): Investigation of the physicochemical, antimicrobial and antioxidant properties of gelatin-chitosan edible film mixed with plant ethanolic extracts. Food Bioscience, 16:17-25.

11. Daniel, A.N. ;Sartoretto, S.M.; Schmidt, G.; Caparroz- Assef S.M .;Bersani Amado, C.A. andCuman, R.K.N.( 2009):Anti-inflammatory and antinociceptive activities of eugenol essential oil in experimental animal models. Revista Brasileira de Farmacognosia 19: 212-217.

12. Dourou, D.; Porto-Fett, A.C.S.; Shoyer, J.E.; Call, G.J.E.; Nychas, E.K. and Luchansky, J.B. (2009): Behavior of Escherichia coli 0157:H7, Listeria monocytogenes, and Salmonella Typhimurium in teewurst, a raw spreadable sausage. Int. J. Food Microbiol., 130: 245-250.

13. El Allaoui .A; Rhazi- Fouzia.F and Oumokhtar.B(2013):Prevalence and antibiogram study of Escherichia coli and staphylococcus aureus in turkey meat in Morocco. Pharmaceut .Anal Acta: 4-9.

14. Eyi- AYLA and ARSLAN-SEZA(2012): Prevalence of Escherichia coli in retail poultry meat, ground beef and beef. Med. Weter., 68 (4):237-240

15. Food and Drug Administration "FDA" (2012): Bad bug book: Foodborne pathogenic microorganisms and natura toxins handbook, 2nd ed. US Food and Drug Administration,Silver Spring, p. 87-92.

16. Feldman, D.; Hoffman, R.and Simpson, J. (2003):The solution for data analysis and presentation graphics.2nd Ed.Abacus Landcripts, Inc., Barkeley, CA, USA.

17. Ferens, W.A.and Hovde, C.J. (2011): Escherichia coli O157: H7: animal reservoir and sources of human infection. Food borne Pathogens and Disease, 8: 465-485.

18. Hassanien - Fatin,S.; Mousa,M.I.; khater- Dalia, F. and Khalil- Rana, M.(2016): Antibacterial effect of rosemary and clove oil on staph. aureus in minced meat.B.V.M.J.31(2):124-129.

19. Hoque,Md.M; Bari,M.L.; Juneja,V.K. and Kawamoto, S.(2008): Antimicrobial activity of cloves and cinnamon extracts against food borne pathogens and spoilage bacteria, and inactivation of listeria monocytogenes in ground chicken meat with their esential oils. Rep. Nat. Food Res. Inst. 72, 9-21.

20. Hmd- Randa, M; Samaha, I.A. and Nossair ,M.A.(2017): Microbiological evaluation of retailed broiler chicken carcasses in Alexandria province. A.J.V.S., 54 (2): 91- 98.

21. Jay, J. M. (1992). Modern Food Microbiology, $4^{\text {th }}$ Ed. NewYork: Chapman and Hall.

22. Khiari, Z.; Pietrasik, Z.; Gaudette, N.J. and Betti, M.(2014): Poultry protein isolate prepared using an acid solubilization /precipitationextraction influences the microstructure, the functionality and the consumer acceptability of a processed meat product. Food Structure.2:49- 60.

23. Marí, S.; Velluti, A.; Ramos, A.J. and Sanchis, V. ( 2004): Effect of essential oils on zearalenone and deoxynivaleno production by Fusarium graminearum in non-sterilized maize grain. Food Microbiology 21: 313-318.

24. Mishra, R.P. and Kalyani, S. (2014):Antimicrobial activities of Syzigium aromaticum L.(Clove). Int. Res. J. Biological Sci., 3(8):22-25. 
25. Nychas, G. J. E. (1995): Natural antimicrobials from plants In G. W. Gould (ed.), New methods of food preservation. Blackie Academic and Professional, London. Pp. 58-89.

26. Nzeako, B.C. ;Al-Kharousi ,Z.S. and Al-Mahrooqui, Z.(2006): Antimicrobial activities of clove and thyme extracts. Sultan Qaboos Univ. Med. J. 6(1): 33-39.

27. Pearson, M.A. and Tauber, W.F. (1984). Processed meat. 2nd ed., A.V.I. Pub. Com. ,Inc.West port Connection. Pp: 93.

28. Rahman, M.A.; Rahman,A.K. M. A.; Islam, M. A. and Alam, M. M.(2017): Antimicrobial resistance of Escherichia coli isolated from milk, beef and chicken meat in Bangladesh. Bangl. J. Vet. Med. 15 (2): 141-146.

29. Raeisi, M. ;Tajik, H.; Yarahmadi, A. and Sanginabadi,S. (2015): Antimicrobial effect of cinnamon essential oil against Escherichia coli and Staphylococus aureus. Health Scope. 4(4): e21808

30. Saad, M.S.; Abou-Elroos-Nahla, A. and Abdel-fadeel, S.R (2018): Incidence and characterization of S.aureus in broiler carcasses. B.V.M.J., 34(2):191-200.

31. Safrudin, I., Maimulyanti, A. and Prihadi, A.R. (2015):Effect of crushing of clove bud (Syzygiumaromaticum) and distillation rate on main constituents of the essential oil. Am. J. Essent. Oil. Nat. Prod., 2(3):1-12.
32. Shaltout, F.A.; El Zahaby- Dina,I.; Lotfy- Lamiaa,M. and E Shorah-Hala,F.(2018): Bacteriological status of chicken meat products marketed at Menofia governorate. B.V.M.J., 34(1):28-40.

33. Sperber, W. H. (2009): Introduction to the microbiologica spoilage of foods and beverages. In: Sperber,W. H. and Doyle, M. P.(Eds). Compendium of the Microbiological Spoilage of Foods and Beverages, Food Microbiology and Food Safety.

34. Spescha, C.; Stephan, R. and Zweifel, C. (2006): Microbiological contamination of pig carcasses at different stages of slaughter in two EU- approved abattoirs. Journal of Food Protect, 69: 2568-2575.

35. Unal, N. and Cinar, O.D. (2012): Detection of Staphylococcal enterotoxins, methicillin-resistant and panton-valentine leukocidin genes in coagulase negative Staphylococci isolated from cows and ewes with subclinical mastitis. Trop. Amin. Health Prod., 44: 369-375.

36. Xuan Binh, D.; Ngoc Minh, N. and ThiNguyet,D. (2017) :Prevalence of Listeria monocytogenes, E. coli, Salmonella Spp. and Staphylococcus aureus bacteria contamination on meat at public market in the north of Vietnam. S.O.J. Microbiol. Infect. Dis., 5(5): 1-22. 